Masayasu Hamaji, Masahiko Miyata, Ryuzo Kawamori, Motoaki Shichiri, Takashi Mashimo, Kazuyasu Nakao, Yasunaru Kawashima

\title{
Blood glucose con- trol by an artificial endocrine pancreas in a patient with phaeochromocytoma
}

In a patient with phaeochromocytoma who presented with unstable diabetes mellitus, an artificial endocrine pancreas was used intraoperatively. Anaesthetic agents included enflurane, nitrous oxide and oxygen. Nicardipine was used to control hypertensive episodes.

The initial blood glucose concentration was 173 $\mathrm{mg} \cdot \mathrm{dl}^{-1}$ and it decreased to $110 \mathrm{mg} \cdot \mathrm{dl}^{-1}$ in response to insulin infusion, but plasma catecholamines were markedly increased. Seventy minutes later, the glucose concentration increased progressively to $249 \mathrm{mg} \cdot \mathrm{dl}^{-1}$ despite massive insulin infusion, maximally $5.64 \mathrm{mU}$. $\mathrm{kg}^{-1} \cdot \mathrm{min}^{-1}$. The blood glucose concentration reached a peak at the time of the ligation of the venous drainage from the tumour and the peak was coincident with that of plasma catecholamine levels (epinephrine: $20.8 \mathrm{ng}$. $\mathrm{ml}^{-1}$, norepinephrine $16.4 \mathrm{ng}^{-\mathrm{ml}^{-1}}$ ). Both glucose and catecholamine concentrations decreased promptly after removal of the tumour and hypotension followed likely because of a persistent vasodilatatory effect of nicardipine.

The profiles of blood glucose, insulin and glucose infusion rates provided by the artificial endacrine pancreas suggested that the insulin resistance began to be reversed shortly after removal of the phaeochromocytoma.

\section{Key words}

SURGERY: phaeochromocytoma; COMPLICATIONS: diabetes mellitus; MET ABOLISM: artificial endocrine pancreas.

From the First Department of Surgery, the Department of Anesthesiology, and the First Department of Medicine, Osaka University Medical School, Fukushima-ku, Osaka, Japan.

Address correspondence to: Dr. M. Hamaji, First Department of Surgery, Osaka University Medical School, 1-1-50, Fukushima-ku, Osaka 553, Japan.
Glucose intolerance is often associated with phaeochromcoytoma and usually disappears after removal of the tumour. During the perioperative period, the majority of patients with phaeochromocytoma have prolonged hyperglycaemia. In addition to the surgical stress, extra-tumour storage of catecholamines is thought to delay the postoperative recovery of glucose metabolism. ${ }^{1}$ Conversely, it was also reported that a profound hypoglycaemia developed in the early postoperative period. . $^{2,3,4}$ Phentolamine and propranolol used before and during operation are thought to exaggerate this complication, but little is known about the postoperative recovery of glucose homeostasis in phaeochromocytoma.

We present a case of phaeochromocytoma in which an artificial endocrine pancreas was used intraoperatively and rapid recovery of glucose homeostasis appeared to occur after surgical resection.

\section{Case report}

A 56-year-old man was admitted for evaluation of unstable diabetes mellitus. He had been receiving insulin for five years. During hospitalization, his blood pressure was noticed to be rather labile; it rose occasionally above $170 / 100 \mathrm{mmHg}$ and followed by a gradual decrease to $100 / 50 \mathrm{mmHg}$. He had no history of a typical hypertensive attack, nor subjective complaints related to blood pressure. Urinary excretion of free metanephrine and normetanephrine were increased to 3.68 and $1.03 \mathrm{mg}$ per day (normally less than 0.3 and $0.08 \mathrm{mg}$ per day, respectively). Abdominal computerized tomography and angiography revealed a solitary left adrenal tumour, $3 \mathrm{~cm}$ in diameter. The profiles of blood glucose concentration varied day by day and 
the patient was regarded as a brittle diabetic; plasma glucose often decreased below $50 \mathrm{mg} \cdot \mathrm{dL}^{-1}$ early in the morning and unexpectedly rose above 400 $\mathrm{mg} \cdot \mathrm{dL}^{-1}$. Various modes of subcutaneous insulin therapy were ineffective in the control of the blood glucose.

Nicardipine, a new calcium-channel blocker* and prazocin were administered orally in increasing doses of 80 to $180 \mathrm{mg}$ for five days and 3 to $8 \mathrm{mg}$ for three days prior to surgery, respectively. A subsequent decrease of blood pressure and tachycardia were treated with transfusion of $1800 \mathrm{~mL}$ of blood.

Since difficulties were anticipated in the control of blood glucose during operation, an artificial endocrine pancreas (Nikkiso, Japan) was used. The artificial endocrine pancreas consists of three units: continuous monitoring of blood glucose using an enzyme electrode, a computer calculating insulin and/or glucose infusion rates and computerized glucose and insulin infusion units. In practice, peripheral blood is withdrawn continuously at the rate of $0.05 \mathrm{ml} \cdot \mathrm{min}^{-1}$ and blood glucose is automatically measured. According to the glucose and insulin algorithm, both of which were previously reported in detail by Kawamori et al.,$^{5}$ insulin (regular insulin) and/or glucose are infused. In short, insulin and glucose infusion rates were independently controlled. Insulin infusion rates were regulated as the sum of the proportional plus derivative mode of blood glucose concentration. Glucose infusion rates were also determined by the same principle. Plasma epinephrine and norepinephrine were serially measured by an automated fluorometric method as previously reported ${ }^{6}$ with minor modifications. ${ }^{7}$

Sequential change in blood pressure and plasma catecholamines following tumour removal are depicted in the upper panel of the Figure. After premedication with diazepam ( $20 \mathrm{mg}$ orally) and hyoscine $(0.3 \mathrm{mg}$ intramuscularly), general anaesthesia was slowly induced by inhalation of enflurane three per cent. Fentanyl $(0.2 \mathrm{mg})$ and diazepam $(10 \mathrm{mg})$ were infused and endotracheal intubation was carried out. Anaesthesia was maintained with enflurane, nitrous oxide and oxygen until the

*2-(N-benzyl-N-methyamino)ethylmethyl 2,6-dimethyl 4-(m-nitrophenyl)-1,4-dihydropyridine-3,5-dicarboxylate hydrochlorise.


FIGURE Changes in blood pressure, plasma catecholamines and profiles of blood glucose response as controlled by an artificial endocrine pancreas. GIR: glucose infusion rate $\left(\mathrm{mg} \cdot \mathrm{kg}^{-1} \cdot \mathrm{min}^{-1}\right)$; IIR: insulin infusion rate $\left(\mathrm{mU} \cdot \mathrm{kg}^{-1} \cdot \mathrm{min}^{-1}\right)$. 
tumour was removed. An abrupt elevation of blood pressure and increase of plasma epinephrine and norepinephrine occurred about 10 min after intubation when $S$ wan-Ganz catheter was placed. Infusion of nicardipine was effective in stabilizing both blood pressure and plasma catecholamines. Progressive increases in plasma catecholamines were noted even before the start of the operation. Plasma cateholamines increased further and blood pressure fluctuated after the start of operation. Nicardipine was infused at a rate varying with the elevation of blood pressure. Plasma catecholamines reached a peak when the drainage veins from the tumour were ligated. Both blood pressure and plasma catecholamines then markedly decreased and urine output was reduced. Enflurane was discontinued. Large volumes $(2700 \mathrm{ml})$ of fluid did not restore blood pressure and bolus injections of methoxyamine $(0.4 \mathrm{mg})$ and ephedrine $(40 \mathrm{mg})$ failed to produce sufficient pressor responses. Pulmonary capillary wedge pressure was $19 \mathrm{~mm} \mathrm{Hg}$ and cardiac output $7.3 \mathrm{~L} \cdot \mathrm{min}^{-1}$, when ligation of the veins from the tumour was completed. The wedge pressure remained at the same level and cardiac output decreased to $4.4 \mathrm{~L} \cdot \mathrm{min}^{-1}$ at the time of tumour removal. Epinephrine infusion $\left(0.6 \mu \mathrm{g} \cdot \mathrm{kg}^{-1} \cdot \mathrm{min}^{-1}\right)$ improved the blood pressure and urinary output. It was discontinued by two hours following surgery.

In the lower panel of the Figure, continuously measured blood glucose concentrations, and glucose and insulin infusion rates are depicted. The initial glucose concentration was $173 \mathrm{mg} \cdot \mathrm{dl}^{-1}$. The "projected" level of glucose was set at $130 \mathrm{mg} \cdot \mathrm{dl}^{-1}$ before the start of operation and then lowered to $100 \mathrm{mg} \cdot \mathrm{dl}^{-1}$. Blood glucose levels decreased in response to insulin infusion, although plasma catecholamines were markedly increased. Seventy minutes later, blood glucose reached a nadir of $125 \mathrm{mg} \cdot \mathrm{dl}^{-1}$. There was then a progressive increase of blood glucose to $249 \mathrm{mg} \cdot \mathrm{dl}^{-1}$ in spite of high dose insulin infusion, maximally $5.64 \mathrm{mU} \cdot \mathrm{kg}^{-1}$. $\mathrm{ml}^{-1}$, until the tumour was removed. Thereafter blood glucose fell to $110 \mathrm{mg} \cdot \mathrm{dl}^{-1}$ and the rate of insulin infusion was negligible. The "projected" level of glucose was restored to $130 \mathrm{mg} \cdot \mathrm{dl}^{-1}$ and the blood glucose increased to $145 \mathrm{mg} \cdot \mathrm{dl}^{-1}$ at the end of the operation. It was found later that peaks of blood glucose and plasma catecholamines were coincident. The artificial endocrine pancreas was disconnected three hours after completion of the operation. Pulmonary interstitial oedema was noted on a chext $x$-ray on the first postoperative day and improved with diuretics. Insulin therapy was unnecessary by seven days postoperatively and the patient is now in good condition with diet therapy alone.

\section{Discussion}

There has been no previous report of the continuous intraoperative monitoring of blood glucose levels in phaeochromocytoma. We found that there was a distinct difference in glucose homeostasis: progressive hyperglycaemia despite large amounts of insulin infusion before removal of the tumour and a rapid decrease of blood glucose with small amounts of insulin infusion required after removal of the tumour. Since the profile of plasma insulin levels was parallel to that of the insulin infusion rate, it is evident that insulin sensitivity began to be restored shortly after removal of the tumour. Since sufficient amounts of glucose are usually given during operation, it cannot normally be observed when the metabolic "turning point" occurs following phaeochromocytoma removal. Our data indicate that the use of an artificial endocrine pancreas allowed the observation of the metabolic recovery which occurred rapidly after removal of the tumour.

Operative stress stimulates cortisol and catecholamine secretion, resulting in hyperglycaemia and lipolysis. We expected a marked change in the plasma free fatty acid levels after removal of the tumour, but there was no noticeable difference. The levels were likely influenced by the heparin given for the placement of the monitoring catheters.

In phaeochromocytoma, the chronic excess of catecholamines has influenced glucose metabolism and a large amount of catecholamines has accumulated in the extra-tumor tissues, and still remains after removal of the tumour. These stores may contribute to the delay in the normalization of glucose metabolism. ${ }^{1,8}$ Conversely, hypoglycaemia can accur in the early postoperative period. In addition to the longstanding alpha-adrenergic inhibition of the pancreatic B-cell, phentolamine and propranolol may induce this complication. ${ }^{2-4}$ The abnormalities of glucose homeostasis observed in the early postoperative period are considered to result from the rapid withdrawal of insulin resistance following resection of the tumour. The 
importance of postoperative glucose monitoring is emphasized and further studies are needed.

Nicardipine was used to control the hypertensive episodes during surgery. Nifedipine has been used for hypertensive control in a case of phaeochromocytoma before surgery. ${ }^{9}$ We found the hypotensive effect of nicardipine to be comparable to that of phentolamine. A disadvantage was its longer halflife $(50 \mathrm{~min}) .{ }^{10}$ The prolonged vasodilatory action resulted in hypotension after removal of the tumour and interstitial lung oedema following overhydration on the first postoperative day. This is the first case where we used nicardipine for intraoperative haemodynamic control and more experience is necessary. The calcium channel blockers can affect insulin secretion and glucose metabolism. Nicardipine has little effect on pancreatic endocrine function, particularly with the total doses of $15 \mathrm{mg}$ used during surgery in our patient. ${ }^{11}$

In conclusion, we used an artificial endocrine pancreas during operation in a patient with phaeochromocytoma who had unstable diabetes mellitus preoperatively. There was a distinct difference in the glucose homeostasis before and after removal of the tumour. Progressive hyperglycaemia in spite of massive infusion of insulin disappeared and insulin sensitivity began to be restored immediately after removal of the tumour. The peak of plasma catecholamines was coincident with that of blood glucose.

\section{References}

1 Hengstmann JH, Dengler HJ. Evidence of extratumorous storage of catecholamines in pheochromocytoma. Acta Endocrinol 1978; 87: 584-95.

2 Martin R, St-Pierre P, Moliner QR. Pheochromocytoma and postoperative hypoglycemia. Can Anaesth Soc J 1979; 26: 260-2.

3 Allen CTB, Imrie D. Hypoglycemia as a complication of removal of a pheochromocytoma. Can Med Assoc J 1977; 116: 363-4.

4 Wilkins GE. Schmidt $N$, Doll WA. Hypoglycemia following excision of pheochromocytoma. Can Med Assoc J 1977; 116: 367-8.

5 Kawamori $R$, Shichiri $M$, Goria $Y$ et al. Importance of insulin secretion based on the rate of changing in blood glucose concentration in glucose tolerance, assessed by the artificial beta-cell. Acta Endocrinol 1978; 339-51.
6 Hamaji M, Seki T. Estimation of catecholamines in human plasma by ion-exchange chromatography coupled with fluorometry. J Chromatogr 1979; 163: 329-36.

7 Seki T, Yamaguchi Y. Fluorimetric determination of catecholamines using glycylglycine as the reagent for post-column derivatization. J Chromatogr 1984; 287: 407-12.

8 Bravo EL, Tarazi RC, Gifford RW, Stewart BH. Circulating and urinary catecholamines in pheochromocytoma. N Engl J Med 1979; 301; 682-6.

9 Serfas D, Shoback DM, Lorell BH. Pheochromocytoma and hypertrophic cardiomyopathy: apparent suppression of symptoms and noradrenergic secretion by calcium-channel blockade. Lancet 1983; 24: 711-3.

10 Higashi S, Shiobara Y. Comparative pharmacokinetics of nicardipine hydrochloride, a new vasodilator, in various species. Xenobiotica 1980; 10 : 447-54.

11 Yajima Y, Sakai H, Takei Y, Nakamura H, Tuyuzaki $M$, Matoba $K$. The effect of calcium-channel blocker, nicardipine, on insulin secretion and glucose tolerance in diabetic patients with hypertension. Sinryo to Shinyaku $1984 ; 21: 1133-40$ (in Japanese). 
Résumé

Chez un patient atteint de phaeochromocytome et présentant un diabète sucré instable, un pancréas artificiel a été utilisé lors de l'opération. L'anesthésie a été accomplie avec de l'enflurane, protoxyde d'azote et de l'oxygène. La nicardipine a été utilisée afin de contrôler les poussées hypertensives.

Initialement la glycémie était de $173 \mathrm{mg} \cdot \mathrm{dl}^{-1}$ et a diminué à $110 \mathrm{mg} \cdot \mathrm{dl}^{-1}$ en réponse à la perfusion d'insuline. Les catécholamines plasmatiques étaient initialement augmentées. Soixante-dix minutes plus tard, la glycémie commença à augmenter progressivement à 249 $\mathrm{mg} \cdot \mathrm{dl}^{-1}$ malgré une perfusion massive d' insuline (maximum $5.64 \mathrm{mU} \cdot \mathrm{kg}^{-1}$ ). La glycémie a atteint un sommet lors de la ligature des veines de la tumeur et ce sommet coincide avec celui des catécholamines plasmatiques (épinephrine: $20.8 \mathrm{ng} \cdot \mathrm{ml}^{-1}$ et norépinephrine: 16.4 $\left.n g \cdot m l^{-1}\right)$. La glycémie ainsi que les catécholamines plasmatiques ont diminué subitement après l'exérèse de la tumeur et l'hypotension qui l'a accompagnée. Cette hypotension serait due d̀ l'effet vasodilatateur persistant de la nicardipine. Une perfusion d'épinephrine etait nécessaire.

Ce profil de glycémie et de taux de perfusion d'insuline fourni par le pancréas artificiel suggère que la résistance à l' insuline commença d retourner à la normale rapidement après l' exérèse de la tumeur chez notre patient. 